\title{
ANALYSIS OF VERBAL PREPOSITIONAL “OF” STRUCTURES
}

\author{
MARIANNA HUDCOVIČOVÁ \\ University of Ss. Cyril and Methodius in Trnava, Slovakia
}

HUDCOVIČOVÁ, Marianna: Analysis of verbal prepositional “of” structures. Journal of Linguistics, 2019, Vol. 70, No 2, pp. $191-199$.

\begin{abstract}
The article presents empirical research of verbal prepositional "of" structures, grammatical collocations of the verb and the preposition OF. The preposition OF belongs among the most frequent prepositions in the English language. The study is based on comparisons of English and Czech sentences containing verbs and prepositions that are followed by the object. Material was taken from the electronic data bank Prague Czech-English Dependency Treebank 2.0. The structures were examined and analyzed from morphological, syntactical and semantic points of view. The aim of the study is to create English-Czech verbal prepositional counterparts; to create verbal prepositional groups on the grounds of the similar semantic, syntactic features; to identify the features that are the same for each verb group and generalize them; to identify trends and tendencies for verbs when they collocate with a certain preposition. The findings are presented in several charts and tables.
\end{abstract}

Keywords: verbal prepositional structure, grammatical collocations, verbal semantic group, preposition "of"

\section{AIMS OF RESEARCH}

There are 83 simple prepositions in English. For the analysis, one of the most frequent ones was chosen, the preposition OF. Verbal prepositional groups (verb complementation) are to be established due to similar semantic and syntactic features. Their generalization, the trends in verbs collocating with a particular preposition will be sought. This sort of analysis requires study of the context in which the prepositions occur.

The analysis will be based on the following hypothesis: "Regular" verbal collocations prevail over the "irregular", i.e. coincidental contexts. Verbs with a similar meaning belong to the same semantic group and collocate with the same prepositions.

\section{SYNTACTIC AND SEMANTIC ASPECT OF VERBAL PREPOSITIO- NAL STRUCTURES}

In the analysis of prepositional verbal phrases from a syntactical point of view the group of verbs is defined that is usually complemented by and object and 
define transitive verbs. Kudrnáčová [5] contributed to the semantico-syntactical analysis of the selected groups of verbs, i.e. motion verbs. The author postulated that "the number and types of complements (and their possible combinations) are not associated with individual verbs but with verbal classes. A certain set of semantic features is shared by all members of the given verb class. These features then represent those components of the verbal lexico-semantic content that are syntactically relevant, i.e. that determine the verbal syntactic behaviour" (p. 8).

Panevová [7], Levin [6], Anderson [1], Wierzbicka [9] and Jackendoff [3] claim that the syntactic and semantic levels are very closely related. In order to detect the specific features of the verbs and prepositions it is necessary to study both levels of the linguistic system. Katz [4] stated - regarding the analysis of verbal-prepositional structures - that the decomposition of the verb can serve as a key. Quirk et al. [8] and Dušková [2] offer classification of verbs according to semantic criteria, i.e. certain semantic features that are shared by a particular group of verbs. Levin (1993) claims that syntactic properties are semantically determined and sought to what extent the meaning of a verb determines its syntactic behaviour. What is really important is to find an effective method for identification of the relevant components of verbal meanings.

\section{RESEARCH METHODOLOGY}

The source of complete sentences with verbal prepositional structures (VPS) was the Prague-English Dependency Treebank 2.0. The Prague Czech-English Dependency Treebank 2.0 is a sentence-parallel manually annotated treebank. It is a manually parsed Czech-English parallel corpus sized over 1.2 million running words in almost 50,000 sentences for each part. The annotation includes also links to two valency lexicons, PDT-VALLEX for Czech and Engvallex, which contains 6213 valency frames for 3823 verbs for English. PDT-VALLEX holds 10593 valency frames for 6667 verbs. The English part contains the entire Penn TreebankWall Street Journal section. The Czech part consists of Czech translations of all of the Penn-Treebank- WSJ texts. The corpus is 1:1 sentence aligned. I used PMLTQ open source search tool for parallel English-Czech treebanks.

The analysis comprised VPS containing preposition OF in English and their equivalents in Czech (also registered in the full context). The VPS were classified into groups of the verb phrases devised for this study. The VPS belonging to an identical semantic group are examined according to two criteria: syntactic relations and lexico-semantic relations. Next, the tendencies for each semantic group were sought. In the survey, qualitative and quantitative approaches were used and the method of contrastive analysis was applied. 


\section{SEMANTIC GROUPS}

Based on the data taken from the English Dependency Treebank, it was possible to include almost all verbs into semantic groups. The following semantic groups were formed: communication; consist; take away sth. from sb.; be guilty of a crime; purify and ask. Only 4 verbs were not included into semantic groups because they did not share similar lexico-semantic features. (i.e. remain, partake, relieve and dream).

\subsection{Semantic group with the meaning "communication"}

The first group consists of verbs with a similar meaning denoting communication and cognitive processes. The verbs tell, say, talk and speak represent oral communication and transmission of messages. These verbs collocate with other prepositions, e.g. the verb talk with prepositions to, of, about, with and at, each with a difference in meaning. The verbal prepositional structure hear of denoting getting information through an audio channel belongs to this group as well.

The verbs notify and inform can be considered synonymous. In Czech they collocate with the preposition o, e.g. uvédomiti o plánu, informovat o; they already put warning labels in their catalogs informing customers of the one-party law již do katalogů zařazují varování informující zákazníky o zákoně o jednostranném souhlasu'. Together with the preposition of and the postponed nominal phrase, e.g. notify of invitation, plan, plot, responsibility, transaction, they express the subject of the communication. The verb warn can be considered as a synonym of notify or inform, only with a stronger meaning to inform someone of a possible danger or problem.

The verbs think, know and learn can be classified as verbs denoting cognitive processes. The verbal prepositional structure think of was the most frequent in the group that is collocated with the preposition of in this research. It was translated into Czech as myslet o, uvažovat o, vzpomenout si na or prijit na. Translation of the verbal prepositional structure think of depends on the context of the whole sentence. As the frequency of the verb is high, there are more translation options. The preposition of together with the nominal phrase that follows expresses the topic of the cognitive process - thinking, e.g. think of commuting, cooperation, future, money, etc.

The verbal prepositional structure know of belongs to the group of cognitive

processes as well. It was translated by the Czech structure vědět o, e.g. know of ambition, a plan, the risk, technology, the use, etc. The preposition of/o, together with the nominal phrase, expresses the result of the cognitive process of thinking. The verb know collocates with other prepositions as well, e.g. about, as does the verb think. Unlike the verb think, however, the preposition about is not interchangeable with of. They have, like the verb know, different meanings, e.g. 
know of is defined in the Oxford Advanced Learner's Dictionary as: "to have information about or experience of somebody, something; know about is defined as: to have knowledge of something, to be aware of something."

The last verbal prepositional structure that denotes cognitive processes is learn of, translated into Czech as dozvědět se o, e.g. learn of development, infection, practice, etc. The complete structure refers to the cognitive process of getting information.

The meaning of the verbal prepositional structure assure of is defined in the Oxford Advanced Learner's Dictionary as follows: "to tell somebody something positively or confidently, esp. because they may have doubts about it," e.g. assure of a paycheck. Its Czech translation was 'ujistiti se o platu'.

The verbal prepositional structure convince of expresses an oral communication used to persuade somebody of something. The research material contained such collocations as convince of need, support or worthiness; to convince anti-abortion activists of his stalwart support 'aby přesvědčil aktivisty vystupující proti potratům o své věrné podpoře'. In all cases the structure was translated as presvědčit $o$.

The reaction to persuasion can be an agreement. This is expressed in the verbal prepositional structure approve of, e.g. approve of abortion 'souhlasit s potratmi'. The counterpart of of is $s$.

This structure is defined in the dictionary as: "to say that one is annoyed, unhappy or not satisfied." With this definition comply the phrases complain of loss and policy. The second meaning of the verb complain was found in the context complain of moonlighting. People complain of moonlighting, a person having a second job, when it interferes with the quality of their work or is a conflict of interest.

The most frequent Czech preposition was $o$, e.g. think of - 'myslet o', tell of 'ríct o', talk of - 'mluvit o', say of - 'říct o' and inform of - 'informovat o'. The second most frequent preposition was $n a$, e.g. think of - 'vzpomenout si na, prijít na', warn of - 'upozornit na'. The preposition před occurred once, e.g. warn of 'varovat před'.

\subsection{Semantic group with the meaning "consist"}

This is the second most frequent group, containing the verbs consist, compose, make, and come. The verbs share a similar meaning: to be made of or form from. In the following sentence the verb compose was translated as 'patři'. The translator translated the sentence to make it sound natural in Czech and the verb patrit is a better choice than the original sestávat z čeho, e.g. and a third category is composed of disorders whose treatment is difficult or impossible if a person lacks adequate shelter. 'a do třetí kategorie patří potíže, jejichž léčba je obtížná nebo nemožná, pokud osoba postrádá vhodné př́ístřeší'.

The verb consist was translated as sestávat z, e.g. sestávající ze 100 milionů dolarů 'consisting of \$100 million'. (114) Záruka sestává ze zaručených půjček, 'The collateral consists of collateralized whole loans'. 
The verbal prepositional structure make of occurred only in the passive voice and expresses creation of a product from a raw material, e.g. (115) Cheerios and Honey Nut Cheerios are made of oats 'Řady Cheerios a Honey Nut Cheerios se vyrábějí z ovsa'.

The expression come of has a similar original meaning as the previous verbal prepositional structures. It expresses origin. (116) Ringers, she added, are "filled with the solemn intoxication that comes of intricate ritual faultlessly performed". 'Zvoníci, dodala, jsou "prodchnuti slavnostním opojením, které vychází z rafinovaného, dokonale provedeného obřadu".

The preposition $z$, the Czech equivalent to the English of, occurs in all verbal prepositional structures that belong to this group. The preposition makes it clear that the product is made of a certain material.

\subsection{Semantic group with the meaning "take away something from somebody"}

The verbal prepositional structures strip of, defraud of and deprive of denote the definition of this group: to break principle. The verbs share the same meaning: "take away something from somebody." In the case of the verb strip, property or honours is taken away. In the second case, the verb defraud expresses taking something illegally from a person. The last verb deprive denotes taking something necessary or pleasant from someone. Translators used the preposition $o$ in all verbal prepositional structures to specify what is being taken away, e.g. ...attempts to strip the president of his powers 'zkoušely připravit prezidenta o jeho moc'; to defraud the Army of \$21 million 'připravit armádu o 21 milionů dolarů'; deprive of right 'připravit o právo'.

\subsection{Semantic group with the meaning "be guilty of a crime"}

There are two prepositional structures with the preposition of that express the meaning to be guilty of a crime, e.g. accuse of "to say that somebody done something wrong, is guilty of something or has broken the law" and convict of: "to decide in a law court that somebody is guilty of a crime". Both of them are translated by the preposition $z$, accuse of - 'vinit' $z$ and convict of - 'uznat vinným $z$ '. The preposition of/z expresses origin, e.g. (117) I'm not accusing insurers of dereliction of duty. Neviním pojišt'ovny ze zproneveréení se povinnosti'. In the following example, the preposition of/ $z$ is used as the only preposition that collocates with the verbs accuse and convict, e.g. ... when someone is convicted of a felony. '... pokud je někdo uznán vinným ze zločinu'. In the survey, expressions were found describing various kinds of crime that collocate with the preposition of, e.g. convict of trespassing, crime, extortion, felony or kidnapping.

\subsection{Semantic group with the meaning "purify"}

The meaning of the verb clear somebody of something is: "to show a person's innocence". Translation of this verb was identical with the verbal prepositional structure cleanse of 'očistit od'. The verbs, however, have different meanings. By the verb clear the original meaning "to purify" is shifted into a metaphoric or figurative meaning. 
The verbal prepositional structure cleanse of is defined in the Oxford Advanced Learner's Dictionary as follows: "to make somebody or something thoroughly clean." The survey brought two occurrences of this verbal prepositional structure. In the first case, the meaning is original, to wash away dirtiness, e.g. cleanse of muck. In the second example the meaning is figurative, e.g. cleanse of $\sin$. The preposition of/od with the verbs clear and cleanse expresses "getting rid of something".

\subsection{Semantic group with the meaning "ask"}

There are two verbal prepositional expressions with the same fixed structure, i.e. ask something of somebody and require something of somebody. It can be said that the verb ask represents a mild form of request. Czech translators used the same Czech verb in both cases: vyžadovat od, e.g. (118) He says the big questions aren't asked of companies coming to market. 'Říká, že odpovědi na hlavní otázky se od společností, které přicházejí na burzu, nevyžadují'. (119) It is required of me that I give evidence. 'Vyžaduje se ode mně, že podám důkazy'.

The Czech counterpart of the preposition of is again $o d$, which expresses an administrator of the request.

\subsection{Other verbal prepositional structures taking the preposition "of"}

There are verbs that cannot be put into any group because of their different lexico-semantic features. The following verbal prepositional structures taking the preposition OF were found in the survey material and classified with this last miscellaneous group, e.g. remain of, partake of, relieve of and dream of.

Prepositional structures are translated into Czech by using different prepositions that are connected with verbs. The verbal prepositional structure remain of was translated into Czech as zuistat z, e.g. what remains of the oil tycoon's once-vast estate 'co pak zůstane z kdysi obrovského majetku olejového magnáta'.

The verbal prepositional structure partake of, synonymous with the verb take part means "to become involved or take part in something". It is interesting that this verb with the previous meaning collocates in English with the preposition of, which expresses mainly the partitive meaning, not sharing or involvement. In Czech or Slovak it collocates with $n a$, which denotes involvement, e.g. domestic franchisees apparently didn't partake of the improvement. 'domácí provozovatelé licence se zjevně na tomto zlepšení nepodíleli'.

The verbal prepositional structure relieve of expresses the meaning "to release somebody from a duty or task by taking their place or finding somebody else to do so." It was translated as e.g. relieve of duty 'uvolnit z funkce'. The Czech counterpart $z$ denotes, together with the nominal phrase duty, a partitive object.

The third verbal prepositional structure dream of was translated as snit $o$. The preposition of/o expresses together with the object the topic of dreaming, e.g. (120) It's one more, too, for the fans who dream of a season that never ends. 'Je to také 
další př́ležitost pro fanoušky, kteří sní o sezóně, která nikdy neskončí’. The verb dream may collocate with about, and it is interchangeable with of.

In all three cases, a different Czech counterpart of the English preposition of was used. The verbal prepositional structures from the last group occurred once or twice. It is therefore difficult to analyze semantic features which they might have shared.

\section{DISCUSSION ON THE VERBAL PREPOSITIONAL "OF" STRUCTURES}

The most frequent prepositional of structure was the verbal prepositional structure think of, which occurred 34 times. In second place was make of with 30 occurrences. Consist of with 27 structures came third. Among the 20 most frequent structures, 12 belong to the group with the meaning "communication and cognitive processes", e.g. think of, say of, notify of, know of, approve of, inform of, warn of, learn of, tell of, talk of, convince of, and speak of. It means that more than the half of the structures collocating with of expresses various ways of communication or knowledge. The group of structures representing the meaning "consist", "take away something from somebody" or "to be guilty" is relatively small with two or three occurrences. The group "communication and cognitive processes" is the largest group and moreover, the most frequently used verbs belong to it. It can be said that communication itself is vitally important in human society. Therefore the ways of communication and their expression vary considerably. This may be the reason why the verbs of this type are the most numerous.

In the most frequent group "communication," the preposition of with the nominal phrase that follows expresses mainly the topic of communication, e.g. say of resignation or the result of a cognitive process: getting information, e.g. know of technology. The meaning of the preposition of in the second group "consist" represents, together with the nominal phrase, the partitive object.

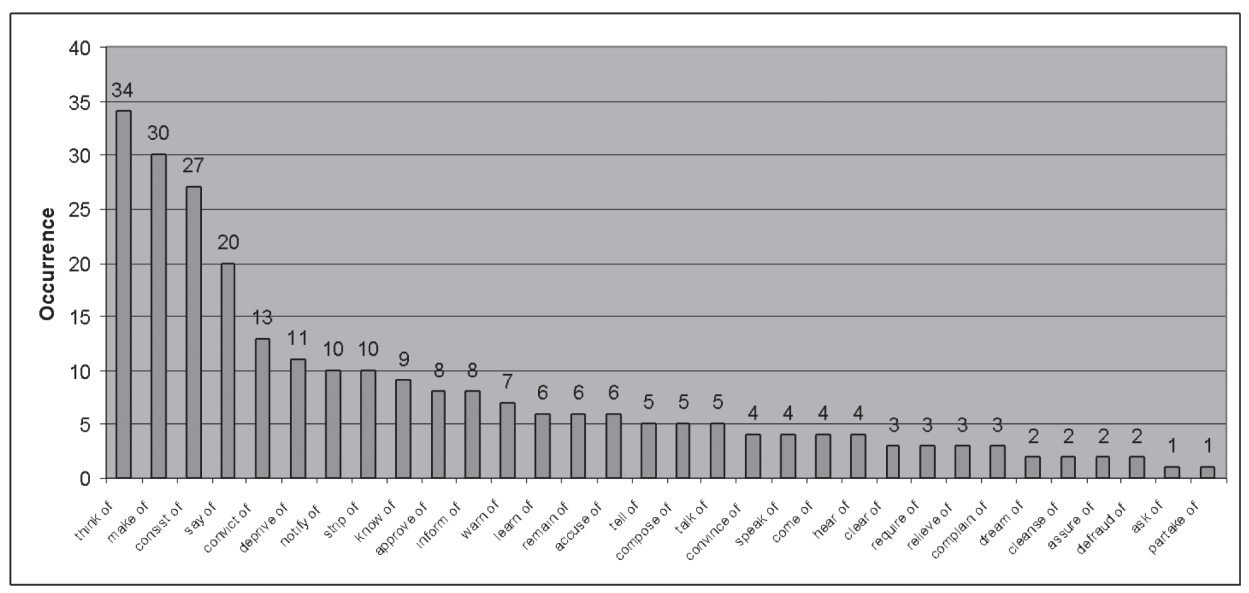

Chart 1. Number of occurrences of verbal prepositional OF structures 


\begin{tabular}{|l|l|r|}
\hline think of & myslet o, uvažovat o, vzpomenout si na, přijít na & 34 \\
\hline make of & vyrábět z, vytěžit z & 30 \\
\hline consist of & sestávat z & 27 \\
\hline say of & ř́́ct o, uvádět o, prohlásit o & 20 \\
\hline convict of & uznat vinným z & 13 \\
\hline deprive of & připravit o & 11 \\
\hline notify of & uvědomiti o & 10 \\
\hline strip of & připravit o & 10 \\
\hline know of & vědět o & 9 \\
\hline approve of & souhlasit s & 8 \\
\hline inform of & informovat o & 8 \\
\hline warn of & varovat před, upozornit na & 7 \\
\hline learn of & dozvědět se o & 6 \\
\hline remain of & zůstat z, zbýt z & 6 \\
\hline accuse of & vinit z & 6 \\
\hline tell of & ř́́ct o & 5 \\
\hline compose of & sestávat z & 5 \\
\hline talk of & mluvit o & 5 \\
\hline convince of & přesvědčit o & 4 \\
\hline speak of & svědčit o & 4 \\
\hline come of & vycházet z & 4 \\
\hline hear of & slyšet o & 4 \\
\hline clear of & očistit od & 3 \\
\hline require of & vyžadovat od & 3 \\
\hline relieve of & uvolnit z & 3 \\
\hline complain of & stěžovat si na & 3 \\
\hline dream of & snít o & 2 \\
\hline cleanse of & očistit od & 2 \\
\hline assure of & ujistiti se o & 1 \\
\hline defraud of & připravit o & 1 \\
\hline ask of & vyžadovat od & 258 \\
\hline partake of & podílet se na & \\
\hline Total & & 2 \\
\hline & & 2 \\
\hline
\end{tabular}

Tab. 1. English verbal prepositional OF structures and their Czech equivalences with number of occurrences

\begin{tabular}{|l|r|}
\hline Group "communication" & $\mathrm{O} / 106 ; \mathrm{NA} / 15$ \\
\hline Group "consist" & $\mathrm{Z} / 72$ \\
\hline Group "take away sth. from sb." & $\mathrm{O} / 23$ \\
\hline Group "be guilty of a crime” & $\mathrm{Z} / 19$ \\
\hline Group "purify" & $\mathrm{OD} / 5$ \\
\hline Group "ask" & $\mathrm{OD} / 4$ \\
\hline
\end{tabular}

Tab. 2. Occurrence of Czech equivalent prepositions in semantic groups 
The data reveal that each semantic group is represented by one preposition, with one exception. The most frequent group, "communication", was represented by two prepositions of which $\mathrm{O}$ represents $88 \%$ and NA $12 \%$. This is due to the shifted meaning of think of, which was translated according to the context as: prijiit na.

The most frequent equivalency was $\mathrm{OF} / \mathrm{O}$. It can be found in connection with verbs expressing the topic or subject of communication. The second most frequent equivalency is $\mathrm{OF} / \mathrm{Z}$, found in the semantic group "consist," detecting the origin or material from which the product was made.

Occurrence of one preposition confirms hypothesis that "Occurrence of the "regular" verbal prepositional phrases prevail over "irregular coincidental" ones." The survey produced 28 "regular" verbs that collocate with the preposition of, 'regular' referencing verbs that can be classified and put into semantic group together with verbs of similar semantic features. There were only four "irregular" verbs which cannot be put into any semantic group. That also confirms hypothesis that "verbs with a similar meaning belong to the same semantic group and are bound with the same preposition." The most frequent group contains many verbs expressing communication, e.g. oral communication is served by the verbs say, tell, talk and speak.

\section{References}

[1] Anderson, J.M. (1971). The Grammar of Case: Towards a Localistic Theory. Cambridge, Cambridge University Press.

[2] Dušková, L. et al. (1988). Mluvnice současné angličtiny na pozadí češtiny. Praha, Academia.

[3] Jackendoff, R. (1992). Semantic Structures. Cambridge, Massachusetts: The M.I.T. Press.

[4] Katz, L. (2003). Semantics. $2^{\text {nd }}$ ed. Oxford, Blackwell Publishing.

[5] Kudrnáčová, N. (2008). Directed Motion at the Syntax-Semantics interface. Brno, Masarykova Univerzita.

[6] Levin, B. 2009. English Verb Classes and Alternations. A Preliminary Investigation. Chicago, The University of Chicago Press.

[7] Panevová, J. (1974). On Verbal Frames in Functional Generative Description I. The Prague Bulletin of Mathematical Linguistics, 22.

[8] Quirk, R., Greenbaum, S. et al.(1985). A Comprehensive Grammar of the English Language. London, Longman.

[9] Wierzbicka, A. (1988). The Semantics of Grammar. Amsterdam, John Benjamins. 